\title{
GANESA SEBAGAI DEWA KEBENCANAAN DI BLITAR
}

\author{
Ganesa as The God of Disaster in Blitar
}

\author{
Muhamad Satok Yusuf \\ Mahasiswa Arkeologi Fakultas Ilmu Budaya Universitas Udayana \\ Jalan Pulau Nias Nomor 13 Denpasar \\ E-mail: denjatayu2@gmail.com
}

\begin{abstract}
Ganesa is one of the popular gods in Nusantara since the 8th AD. The popularity of this elephant-headed god does not only come without reason, but it is also accompanied by his role as provider and antidote to existing disasters, both naturally and socially. This study will discuss Ganesa's role in Blitar in the form of sculpture and their placement in a potentially disaster-prone area. The data collection techniques are through an observation and literature review with qualitative descriptive analysis. The result of this study indicates that Ganesa's role is a sign of past human efforts to gain courage and blessings in the face of disasters. The Ganesa is placed in disaster-prone areas such as volcanic mountains, floods and even in the rice fields. The placement of these sculptures is not only in a complete sacred building such as candi, but can be placed in open-space such as balai.
\end{abstract}

Keywords: Ganesa, Blitar, sculpture, worship, disaster

\begin{abstract}
Abstrak
Ganesa merupakan salah satu dewa populer di Nusantara sejak abad ke-8 Masehi. Popularitas dewa berkepala gajah ini tidak datang tanpa alasan, akan tetapi disertai dengan perannya yang menjadi pemberi dan penangkal bencana yang ada, baik bencana alam maupun bencana sosial. Kajian ini berupaya membahas peran Ganesa di Blitar dalam pengarcaan maupun penempatannya dalam suatu wilayah terhadap potensi kebencanaan yang ada. Teknik pengumpulan data yang digunakan melalui observasi lapangan dan kajian pustaka dengan analisis deskriptif kualitatif. Hasil kajian ini menunjukkan bahwa peran Ganesa terhadap kebencanaan yang terjadi di Blitar pada masa Hindu-Buddha menjadi penanda usaha manusia di masa lalu untuk mendapatkan keberanian dan berkah dalam menghadapi bencana. Ganesa ditempatkan pada daerah yang rawan terjadi bencana seperti gunung meletus, banjir, bahkan area persawahan. Penempatan arca ini tidak hanya pada bangunan suci yang lengkap seperti candi, akan tetapi dapat berupa ruang terbuka seperti balai.
\end{abstract}

Kata kunci: Ganesa, Blitar, arca, pemujaan, kebencanaan

\section{PENDAHULUAN}

Hubungan India dengan Nusantara terjalin sejak lama. Bukti pengaruh budaya India di Nusantara secara historis ditandai dengan temuan prasati Yupa di Kutai, Kalimantan Timur. Perkembangan Hindu kemudian muncul di Jawa pada abad ke-5 Masehi. Masyarakat Hindu memuja banyak dewa dengan dewa utama berupa Siwa, Wisnu, dan Brahma. Ganesa muncul sebagai dewa yang populer dari sekian banyak 
dewa Hindu dalam kebudayaan Hindu-Buddha di Jawa (Getty 1971; Sedyawati 1985; Tim Penulisan Sejarah Nasional Indonesia 2008).

Popularitas Ganesa seiring dengan popularitas sekte Saiwa pada abad ke-8 Masehi di Jawa Tengah berdasarkan tinggalan candi yang ada (Sedyawati et al. 2017). Ganesa merupakan putra Siwa yang kehadirannya berada di relung belakang (biasanya di relung sisi timur atau barat pada candi bernafaskan Hindu-Siwa) suatu bangunan suci. Ganesa dalam panteon Siwa dikenal sebagai Dewa Pengetahuan. Hal ini dapat ditelusuri dari kisah mitologi Ganesa sebagai pencatat Weda. Ganesa menjadi murid Rsi Wiyasa yang membukukan ajaran Weda menggunakan pena dari gadingnya (Getty 1971:4).

Pemujaan Ganesa lazimnya dilakukan bersamaan dengan keluarga Siwa lainnya, seperti Siwa dan Parwati yang kadang diwakili lingga-yoni, Durga Mahisasuramardhini, Agastya, Mahakala dan Nandiswara. Padahal, pada beberapa lokasi di Blitar ditemukan arca Ganesa individu tanpa disertai arca panteon Siwa yang lain, seperti pada temuan arca Ganesa Boro dan Ganesa Kinewu. Temuan tersebut mengindikasikan bahwa kehadiran Ganesa secara individu di kalangan masyarakat Blitar kuno sangat vital. Ganesa dipuja oleh masyarakat Blitar kuno secara pribadi dengan tujuan tertentu. Pemujaan Ganesa sebagai dewa individu menarik untuk dikaji, khususnya dalam kehidupan beragama masyarakat Blitar pada masa Hindu-Buddha.

Penelitian tentang Ganesa sebagai Dewa Kebencanaan khususnya di Blitar secara spesifik belum ada. Kehadiran Ganesa sebagai individu menarik untuk dikaji lebih mendalam. Terlebih, penempatan lokasi arca tersebut berada di wilayah yang rawan bencana, seperti Gunung Kelud dan Sungai Brantas. Berdasarkan uraian tersebut, maka dirumuskan permasalahan berupa bagaimana pengarcaan Ganesa sebagai Dewa Kebencanaan di Blitar, bentuk pemujaan, dan keletakannya pada wilayah rawan bencana.

Penelitian diawali dengan pengumpulan data yang dilakukan dengan teknik observasi terhadap objek, perekaman data baik secara tekstual maupun gambar, serta kajian pustaka sebagai penuntun analisis. Pengumpulan data dilakukan dengan eksplorasi temuan arca Ganesa sebagai dewa individu di Blitar dan informasi lingkungan pendukungnya. Selanjutnya adalah justifikasi tentang keaslian artefak dan keletakan insitu atau eksitu dari arca tersebut.

Setelah semua data terkumpul, kemudian dilakukan analisis deskriptif kualitatif. Analisis deskriptif kualitatif bermaksud memahami fenomena tentang apa yang dialami oleh subjek penelitian, misalnya perilaku, persepsi, motivasi, tindakan, dan lain-lain secara holistik dengan cara deskripsi dalam bentuk kata-kata dan bahasa, pada suatu konteks khusus yang alamiah dengan memanfaatkan berbagai metode ilmiah (Moleong 2014:6). Objek penelitian tersebut dalam konteks arkeologi berupa arca Ganesa dan kondisi lingkungan pendukungnya.

Penelitian ini menggunakan pendekatan ikonografi untuk menguraikan perincian dari simbol-simbol yang disematkan pada arca Ganesa dan pendekatan arkeologi keruangan. Ilmu ikonografi mempelajari tentang perincian dari figur yang dipuja dalam bentuk arca, lukisan, mosaik dan lain-lain (Rao 1968). Selanjutnya, tentang arkeologi 
keruangan menurut David Clarke adalah pendekatan arkeologi yang memfokuskan perhatian pada dimensi ruang dari benda-benda arkeologi dan situs. Terdapat tiga hal pokok dalam arkeologi keruangan, yaitu keletakan elemen artefak, satuan ruang tempat beraktivitas, dan keterkaitan semua unsur tersebut dalam satuan ruang dengan skala yang berbeda (Clarke 1977).

\section{PEMBAHASAN}

\section{Mitologi Ganesa sebagai Penghalang Rintangan}

Blitar merupakan wilayah yang terhampar di selatan lereng Gunung Kelud hingga berbatas Samudera Hindia di sebelah selatan. Wilayah yang diapit oleh Kabupaten Malang di sisi timur dan Kabupaten Kediri serta Tulungagung di sisi barat ini seringkali dilanda bencana letusan Gunung Kelud. Gunung Kelud telah memuntahkan lahar dan abu kurang lebih 32 kali dalam kurun tahun 1000 - 2007 (Cahyono 2012:87). Letusan Gunung Kelud terbaru terjadi pada tahun 2014, abunya hingga menutupi Kota Yogyakarta dan Surabaya.

Kengerian letusan Gunung Kelud telah tercatat dalam karya sastra masa Majapahit. Mpu Prapanca dalam kakawin Nagarakrtagama irama 1 bait ke-4 menyebutkan bahwa pada tahun rttuśarena (1256 Saka/ 1334 Masehi) Gunung Kampud (nama kuno Gunung Kelud) meletus dahsyat. Letusannya diiringi dengan gempa bumi, hujan debu, suara gemuruh, dan halilintar yang menewaskan orang-orang hina dan jahat. Saat peristiwa tersebut terjadi, Hayam Wuruk lahir di Kahuripan. Selain hujan abu, letusan Kelud juga menyebabkan banjir lahar yang menerjang berbagai wilayah di sekitarnya, yang dikenal sebagai guntur pabanyu pindah dalam Kitab Pararaton (Cahyono 2012; Riana 2009:54).

Kebencanaan pada dasarnya merupakan bentuk halang rintang manusia dalam menjalani kehidupan. Aktivitas manusia menjadi terganggu dan dapat berakibat fatal, seperti hilangnya harta benda dan jiwa akibat bencana. Manusia pun kemudian berusaha mengatasi bencana yang dihadapinya, baik secara fisik seperti mitigasi bencana maupun secara nonfisik melalui kekuatan magis yang menjadi pelindung. Kebudayaan Hindu mengenal beberapa dewa sebagai pelindung manusia, antara lain Dewi Durga yang menjadi pelindung peperangan, Dewa Wisnu yang menyelamatkan manusia sebagai awatara dan Dewa Ganesa sebagai penguasa segala rintangan.

Kehadiran Ganesa menjadi penting dalam strategi pencegahan kebencanaan. Terdapat banyak mitologi Ganesa yang dihubungkan dengan bencana dan perannya sebagai penghalau rintangan tersebut. Versi pertama tentang mitologi kelahiran Ganesa berasal dari kitab Lingapurāṇa dan kitab Varahāpurāna. Karya sastra tersebut menjelaskan tentang para asura yang diberkati Siwa karena ketulusan memujanya. Anugerah kekuatan yang diberikan Siwa kepada para asura rupanya disalahgunakan untuk mengganggu para pemuja yang akan melakukan pemujaan terhadap para dewa. Dewata pun resah dan kemudian memohon bantuan Siwa. Siwa melalui amsa (bagian tubuh Siwa) berubah wujud menjadi anak kecil yang lahir dari rahim Parwati. Anak 
tersebut diberi nama Wighneśwara (penguasa rintangan) yang diberi tugas untuk menggagalkan upaya para asura (Rao 1968).

Mitologi lain tentang Ganesa berhubungan dengan peperangan dan rintangan. Siwapurana menceritakan kehebatan Ganesa melindungi ibunya, Parwati yang sedang mandi. Kala itu Parwati menciptakan Ganesa berwujud lelaki tampan bernama Wighneśwarā dari tubuhnya sebagai penjaga istana dan berpesan siapapun dilarang masuk istana ketika ia masih mandi. Siwa datang dan hendak masuk istana, namun dicegah Ganesa. Pertempuran berlangsung seru hingga Siwa berhasil menebas kepala Ganesa menggunakan trisula. Parwati yang mengetahui hal tersebut marah dan menuntut Siwa. Siwa kemudian memohon bantuan Brahma dan disarankan untuk mencari kepala pengganti berupa makhluk yang sedang tidur menghadap ke utara. Para gana diutus Siwa ke bumi dan menemukan kepala gajah yang kemudian dipasangkan ke badan Ganesa (Getty 1971; Rao 1968; Sedyawati 1985:188).

Eksistensi Ganesa juga dikenal di tanah Jawa. Mpu Dharmaja dari Kerajaan Kadiri melalui Kakawin Smaradahana menceritakan kelahiran Ganesa sebagai penghilang bencana yang menimpa kahyangan. Suatu waktu kahyangan geger atas serangan raksasa Nilarudraka yang ingin mengkudeta. Siwa yang sedang bertapa di Gunung Mahameru tidak bisa diganggu siapapun. Dewa Kama atas permintaan para dewa membangunkan Siwa dan berakibat dirinya terbakar. Akhirnya Siwa kembali bergairah dan menemui Parwati berkat panah asmara yang dilepaskan Dewa Kama. Parwati kemudian mengandung anak lelaki. Dewa Indra pada suatu waktu ke kahyangan sambil menuntun gajah kendaraannya yang bernama Airawata, hendak menemui Parwati yang ngidam. Parwati terkejut melihat Airawata dan seketika ia melahirkan anak berkepala gajah. Anak tersebut kemudian dinamai Ganesa. Ia menjadi pahlawan kahyangan sebab berhasil membunuh Nilarudraka (Atmadja 2001:20-21; Sedyawati 1985; Zoetmulder 1985).

\section{Keletakan dan Pemujaan Arca Ganesa}

Wilayah Blitar secara historis telah menjadi bagian dari Kerajaan Mataram Kuno, Kadiri, Singhasari, dan Majapahit yang meninggalkan berbagai bangunan yang bernafaskan Hindu. Terdapat setidaknya 30 bangunan suci dan 40 prasasti tersebar di berbagai wilayah Blitar, bernafaskan Hindu dan Buddha (Yusuf 2020:44-47). Tinggalan arca pun ratusan, sebagian masih berada di tempat aslinya, sebagian disimpan di museum, dan sisanya diletakkan di rumah warga serta danyangan ${ }^{l}$.

Arca Ganesa di Blitar ditemukan secara individu atau berkelompok dalam panteon arca Siwa. Arca-arca Ganesa yang ditemukan individu adalah Ganesa Kinewu, Ganesa Boro dan Ganesa Candi Panataran. Ketiga arca Ganesa tersebut memiliki keunikan masing-masing dan berasal dari masa yang berbeda. Arca-arca tersebut menggambarkan Dewa Ganesa yang dipuja sebagai individu dan berkaitan dengan kebencanaan yang ada di sekitarnya.

\footnotetext{
${ }^{1}$ Tempat suci peribadatan masyarakat Jawa modern
} 
Arca Ganesa pertama disebut Ganesa Kinewu, ditemukan di Desa Jiwut, Kecamatan Nglegok, Kabupaten Blitar. Jan Laurens Andries Brandes dalam OudJavaansche Oorkonden No. XXVI menyebutkan bahwa arca ini berada di Pendopo Kabupaten Blitar. Pada sandaran bagian belakang terdapat Prasasti Kinewu yang ditulis dalam aksara dan bahasa Jawa Kuno. Prasasti berisi tentang permintaan pembebasan pajak oleh rāma Kinwu kepada Raja Balitung pada tahun 829 Saka/907 Masehi (Brandes, 1913:34-35). Warga Dusun Klampok Desa Jiwut pada tahun 1956 menemukan lapik arca tersebut yang merupakan sambungan Prasasti Kinewu (Machi and Kartakusuma 1996:30-32). Kini arca tersebut disimpan di Museum Penataran dengan nomor inventaris XIII/49 (Gambar 1 dan 2).

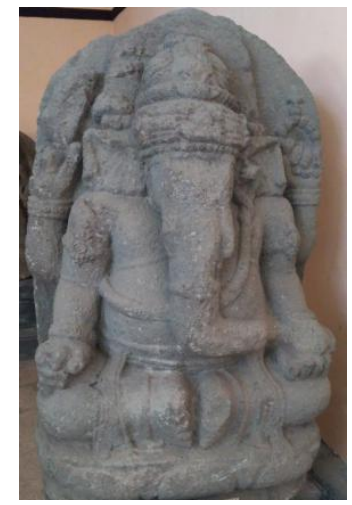

Gambar 1. Ganesa Kinewu Sumher Yusuf 2019

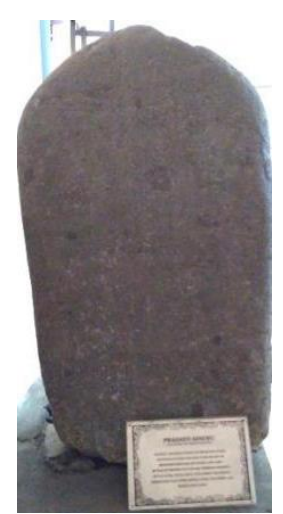

Gambar 2. Prasasti Kinewu Sumher Yusuf 2019

Arca Ganesa Kinewu digambarkan duduk seperti bayi di atas padmasana ${ }^{2}$ ganda dengan perawakan gendut, berkepala serta bertelinga gajah. Ganesa mengenakan jamang dan mahkota pilinan rambut dengan hiasan ardhacandrakapala ${ }^{3}$. Ia hanya memiliki gading utuh di sebelah kanan (ekadanta ${ }^{4}$ ). Terdapat halo di belakang kepala Ganesa. Arca digambarkan bertangan empat, mengenakan atribut berupa tasbih di tangan kanan atas, kapak di tangan kiri atas, mangkuk di tangan kanan bawah, dan gading di tangan kiri bawah. Ia mengenakan kain sebatas pinggang hingga lutut. Perhiasan yang dikenakan arca tersebut, antara lain nagopawita ${ }^{5}$, ikat dada, kelat bahu bermotif permata, gelang tunggal, ikat perut, dan uncal menjuntai ke depan kaki.

Pemilihan arca Ganesa sebagai perantara penulisan prasasti tampaknya juga berkaitan dengan maksud dalam prasasti tersebut, walau tidak terlalu signifikan. Ganesa adalah dewa penghalang rintangan (Wighneśwarā) dalam situasi apapun. Dewa Ganesa memiliki kendaraan berupa tikus bernama mūṣaka yang berasosiasi dengan pertanian. Tikus merupakan hama sawah yang sangat merugikan petani karena merusak pertanian. Pendapat tersebut didasarkan atas kata mūṣaka yang dirunut dalam bahasa Sansekerta berasal dari kata $m \bar{u} s$, berarti merampok atau mencuri (Krishan 1982). Ganesa dengan

\footnotetext{
${ }^{2}$ Lapik arca berbentuk kelopak bunga teratai

${ }^{3}$ Hiasan tengkorak menggigit bulan sabit, atribut khas Dewa Siwa dan keluarganya

${ }^{4}$ Ganesa yang bergading tunggal

5 Tali kasta berbentuk naga
} 
menundukkan tikus sebagai kendaraannya menunjukkan ia menghalangi bencana yang menyerang pertanian. Oleh sebab itu, kemungkinan alasan Raja Balitung mengeluarkan Prasasti Kinewu pada sandaran arca Ganesa bertujuan memberikan anugerah serta mengibaratkan dirinya sebagai pelindung petani Kinwu layaknya Ganesa yang menjadi pelindung pertanian.

Temuan arca kedua adalah Ganesa Boro yang ada di Dusun Boro, Desa Tuliskriyo, Kecamatan Sanankulon, Kabupaten Blitar. Arca tersebut berasal dari Jimbe yang kemudian dipindahkan ke Boro (Sedyawati 1985). Arca dipahat dari batu andesit dengan gaya mewah, berkepala gajah sedang duduk seperti bayi di atas lapik susunan tengkorak. Raut arca merupakan perpaduan antara tenang dan bengis berdasarkan penggambaran mata yang setengah terpejam dan alis yang tebal. Arca bertangan empat, tangan kanan atas memegang kapak, tangan kiri atas memegang tasbih, tangan kanan bawah memegang mangkuk dan tangan kiri bawah memegang gading. Busana yang dikenakan arca sangat raya, antara lain mahkota tabung, anting-anting, nagopawita, kelat bahu, gelang, ikat dada, ikat perut, uncal dan kain sebatas pinggang hingga mata kaki bermotif kawung. Terdapat hiasan kepala kala pada bagian sandaran arca. Lapik arca sisi kiri melingkar ke kanan terdapat inskripsi dalam aksara dan bahasa Jawa Kuno berbunyi "hana ghaṇa hana bumi" (arti= ada ghaṇa ada bumi) (Gambar 3 dan 4).

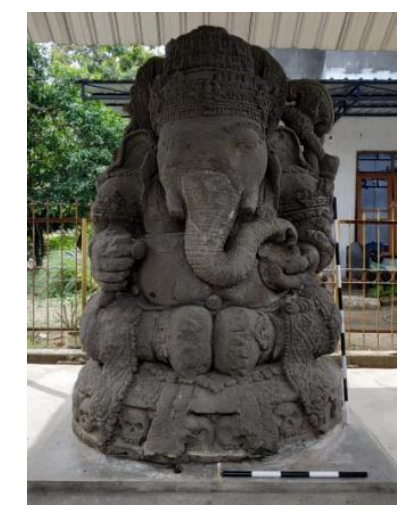

Gambar 3. Arca Ganesa Bor Sumber: Yusuf, 2019

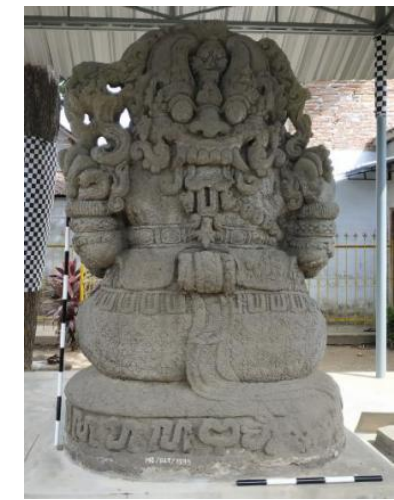

Gambar 4. Stella Arca Ganesa Boro Sumber: Yusuf, 2019

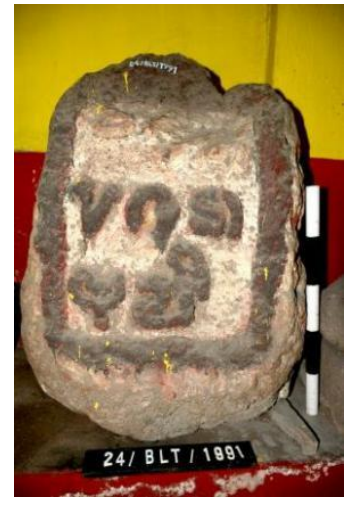

Gambar 5. Prasasti di Kekunoan Jimbe Sumber: BPCB Jatim, 2017

Para peneliti menduga inskripsi yang tercantum dalam lapik arca sebagai candra sangkala. Nicolaas Johannes Krom menyatakan inskripsi tersebut berasosiasi dengan angka tahun 1161 Saka, sedangkan Brandes dan Padmosoekotjo berpendapat jika inskripsi tersebut merupakan angka tahun 1181 Saka (Sedyawati 1985). Jika demikian, maka dapat ditarik penanggalan relatif dari arca tersebut berasal dari masa akhir Kadiri. Terdapat temuan ambang pintu bertulis "1124" sejauh $1 \mathrm{~km}$ di utara arca yang menunjukkan Era Raja Srengga dari Kadiri. Menariknya, di kekunoan Jimbe Mbah Umyang terdapat lempengan batu prasasti bertulis sembilan aksara yang terbaca “... (sa)garā bumi" (Gambar 5). Huruf pada prasasti bergaya Jawa Kuno terpahat jelas 
dengan gaya yang sama dengan inskripsi Ganesa Boro. Mungkin saja kedua prasasti tersebut memiliki hubungan sebagai satu bagian.

Arca Ganesa Boro merupakan arca penjaga bahaya Sungai Brantas sebagai Wigneśwara atau Wignarāja. Pendapat ini dikuatkan oleh Stuterheim yang menyatakan bahwa arca tersebut sebagai penghilang hambatan para pelayar di Sungai Brantas (Getty 1971). Keberadaan Sungai Brantas sangat penting bagi nadi perekonomian dan jalur transportasi pada masa Kadiri, Singhasari, hingga Majapahit. Temuan pintu gerbang pada masa Kadiri di Situs Besole menjadi indikasi kuat bahwa wilayah Besole hingga Jimbe merupakan jalur sibuk pelayaran (Kuswanto 2009:43-53). Hal tersebut diperkuat dengan berita dalam Nagarakrtagama yang menyebutkan perjalanan Hayam Wuruk ke Blitar melewati wilayah utara sungai (Balitar, Lwang Wentar, Palah) dan selatan Sungai Brantas (Lodhaya dan Simping) yang kemudian menuju Surawana (Riana 2009). Tentunya perjalanan tersebut harus menyeberangi Sungai Brantas (Bahasa Jawa =nambang). Aktivitas nambang sebagai profesi di Blitar telah berlangsung sejak era Jayabhaya yang tercatat dalam Prasasti Talan (1058 Saka) (Brandes 1913:164). Bahkan aktivitas penambangan hingga kini masih berlangsung di sepanjang wilayah sebelah barat arca Boro hingga Wonodadi.

Perihal kepala kala di belakang arca diduga kuat memiliki konsep yang sama dengan fungsi dari kepala kala pada ambang pintu candi. Kepala kala menjadi pengusir aura buruk atau penjahat yang berniat buruk terhadap bangunan suci. Menariknya, sang Wighnaraja digambarkan bersama Kala yang keduanya memiliki kesamaan fungsi sebagai pengusir rintangan. Penggambaran dua unsur tersebut menjadi indikasi penggabungan dua konsep kebudayaan India dengan kebudayaan asli Nusantara. Seni kedok muka sebagai pengusir bahaya telah hadir sejak masa Neolitik di Nusantara dan diasosiasikan dengan kala, karang bhoma, rahu atau kirtimukha pada masa HinduBuddha (Soejono 1977:137; Surada 2013:61-62).

Arca ketiga berada di kompleks Candi Panataran, lereng barat Gunung Kelud. Arca terbuat dari batu andesit berwarna merah dan sekarang diletakkan di dalam Candi Angka Tahun (Gambar 6). Arca tersebut ditemukan di depan Candi Angka Tahun, sedangkan kondisi Candi Angka Tahun hanya bagian atapnya saja yang runtuh berdasarkan foto Kinsbergen tahun 1914 yang diunggah di koleksi digital Universitas Leiden (Gambar 7). Ukuran arca tersebut lebih besar dibandingkan lebar pintu candi, sehingga tidak mungkin arca bisa keluar dari candi yang bagian pintunya masih utuh. Berdasarkan kasus tersebut, besar kemungkinan terdapat kesalahan interpretasi rekonstruksi keletakan arca Ganesa yang dilakukan oleh Pemerintah Hindia Belanda. 


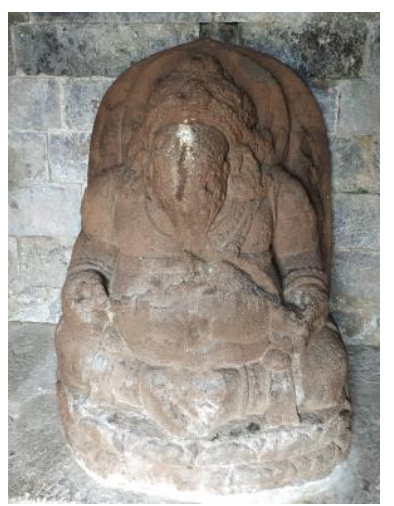

Gambar 6. Arca Ganesa Panataran

Sumber: Yusuf, 2019

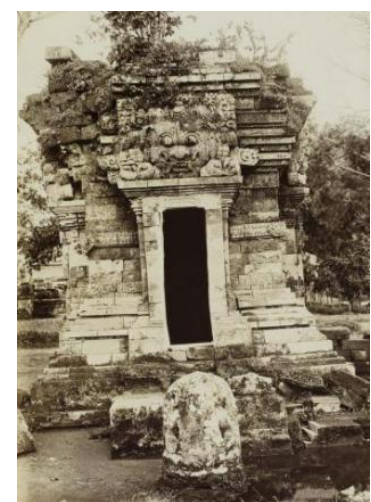

Gambar 7. Arca Ganesa di depan Candi Angka Tahun Sumber: Kinsbergen, 1914

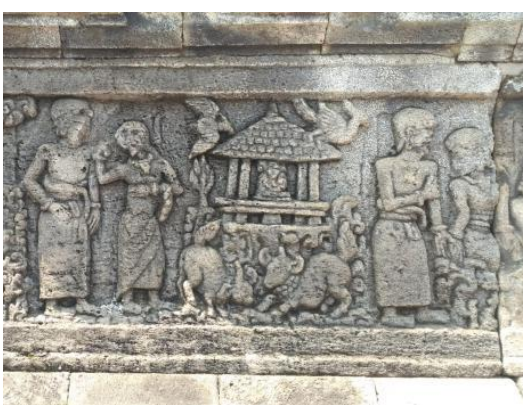

Gambar 8. Relief Ganesa di

Pendapa Teras Candi Panataran Sumber: Yusuf, 2019

Keletakan arca Ganesa tersebut diduga kuat bukan di Candi Angka Tahun, melainkan berada di Pendapa Kecil di depan Pendapa Teras. Bangunan tersebut kini hanya bersisa empat umpak yang terdapat ukiran relief kelinci bulan di keempat sisinya. Interpretasi didasarkan pada perbandingan dengan relief arca Ganesa pada adegan Sri Tanjung di sisi barat Pendapa Teras. Penggambaran relief Ganesa diletakkan di dalam pendapa yang disangga empat umpak, bagian bawah umpak dipahatkan relief kelinci bulan saling berhadapan dan dua burung bertengger pada atap balai (Gambar 8). Relief kelinci bulan di bawah balai relief Sri Tanjung tersebut memiliki kesamaan bentuk dengan pahatan kelinci bulan pada keempat umpak di depan Pendapa Teras. Oleh sebab itu, besar kemungkinan arca tersebut diletakkan di bagian pendapa kecil.

Ganesa Panataran berasal dari periode Majapahit. Hal ini dapat ditelusuri dari adanya hiasan meander pada sisi kanan dan kiri badan Ganesa yang merupakan penciri kesenian Majapahit (Bawono and Zuraidah 2016:1-4). Periode pembuatan arca dapat dibandingan dengan tinggalan yang ada di sekelilingnya. Candi Panataran kaya akan angka tahun, mulai dari 1119 Saka hingga 1337 Saka (Sedyawati et al. 2017). Bangunan terdekat dari umpak tersebut adalah Pendapa Teras yang berangka 1297 Saka dan Candi Angka Tahun yang berangka 1291 Saka, didirikan pada masa pemerintahan Raja Hayam Wuruk dari Majapahit. Kemungkinan arca Ganesa tersebut dibuat sekitar tahun 1291 - 1297 Saka atau malah jauh sebelumnya sebab sang raja juga pernah berkunjung ke Panataran pada 1256 Saka.

Berkaitan dengan pemujaan Ganesa pada bagian muka Candi Panataran dapat ditelusuri berdasarkan mitologinya. Mpu Tanakung dalam Kakawin Siwaratrikalpa menggambarkan Ganesa menjadi dewa yang dipuja pertama sebelum pemujaan lainnya (Teeuw and Tanakung 1969:132-33). Kitab Korawāśrama juga menyinggung bahwa Ganesa mendapat anugerah dari Brahma menjadi yang pertama mencium aroma bunga dan wewangian (Atmadja 2001; Sedyawati 1985).

Pemujaan Ganesa di Percandian Panataran merupakan hal yang menarik. Prasasti Palah memberitakan bahwa Rabut Palah (nama kuno Candi Panataran) merupakan tempat memuja Battara i Palah, sedangkan Nagarakrtagama menyebutkan 
bangunan tersebut didedikasikan kepada Sang Hyang Aśalapati, nama lain Dewa Siwa (Lutfi 1991; Riana 2009). Pemujaan dewa tersebut sangat mungkin berkaitan dengan aspek Siwa sebagai Dewa Nrrti, dewa kesengsaraan. Melalui pemujaan Nrrti, diharapkan pemujanya dihindarkan dari malapetaka (Yusuf 2020). Peran tersebut sama halnya dengan pemujaan Ganesa sebagai Wighneśwāra.

Ketiga arca Ganesa tersebut diletakkan tidak dalam bangunan suci candi, melainkan berada di ruang terbuka berbentuk balai. Penggambaran tersebut didasarkan dari relief adegan Sri Tanjung pada dinding barat Pendapa Teras Candi Panataran yang menunjukkan arca Ganesa diletakkan di balai terbuka. Indikasi selanjutnya yang menguatkan keletakan ketiga arca tersebut adalah bahwa dua sandaran arca Ganesa didapati inskripsi maupun hiasan kala. Tentunya apabila arca dipahatkan dari seluruh sisi, maka tidak mungkin tempat peletakan arca tertutup dinding candi. Oleh sebab itu, bentuk bangunan suci yang mendukung untuk keletakan arca tersebut setidaknya berupa balai, baik yang pondasinya berupa umpak maupun batur. Hal tersebut didukung dengan pendapat Munandar bahwa bangunan berbentuk batur pada bagian atasnya terdapat objek sakral yang dipuja (Munandar 1995:14-16).

Arca Ganesa diletakkan pada tempat-tempat yang berpotensi bencana sebagai pengusir malapetaka. Arca Ganesa pada Candi Panataran memiliki fungsi yang sama dengan Hyang Aśalapati sebagai pelindung dari letusan Kelud. Ganesa Boro menjadi pelindung pelayaran di Sungai Brantas sejak masa Kadiri. Ganesa Kinewu menjadi pelindung bagi pertanian di karāman Kinwu pada masa Mataram Kuno. Selain itu peletakan Ganesa di karāman Kinwu maupun di Dusun Boro juga berkaitan dengan pemujaan Ganesa sebagai grāmadewa, dewa pelindung desa. Hal ini didasarkan atas legitimasi Ganesa pada kitab Korawāśrama yang menggambarkan keberhasilan Ganesa menebak pertanyaan dewa dan mendapat anugerah Dewa Indra agar dipuja di desa-desa (Atmadja 2001; Sedyawati 1985). Ganesa Wighneśwāra menjadi dewa yang mampu membuat pemujanya terhindar dari kebencanaan dan membuat rasa percaya diri para pemuja semakin meningkat dalam menghadapi bencana di Blitar pada masa kuno.

\section{SIMPULAN}

Pemujaan Ganesa di Blitar berkaitan dengan faktor kebencanaan yang melanda wilayah lereng selatan Gunung Kelud, berupa bencana gunung meletus, luapan banjir dan keamanan pelayaran di Sungai Brantas, serta ancaman hama pertanian. Pemujaan Ganesa sebagai Wighneśwara ditunjukkan melalui tiga arca Ganesa yang unik, yakni arca Ganesa Kinewu, Ganesa Boro, dan Ganesa Panataran. Peletakan ketiga arca berada di balai terbuka. Hal itu didasarkan pada relief Sri Tanjung Pendapa Teras Candi Penataran serta pertimbangan bentuk arca yang dipahatkan seluruh bagiannya kecuali arca Ganesa Palah, sehingga tidak sesuai jika arca diletakkan pada ruangan candi. Ganesa juga menjadi dewa yang dipuja pertama sebelum upacara lainnya dan menjadi grāmadewa di desa-desa. Pemujaan Ganesa untuk menguatkan para pemujanya dalam menghadapi kebencanaan yang terjadi di Blitar. 


\section{DAFTAR PUSTAKA}

Atmadja, Nengah Bawa. 2001. Ganesa Sebagai Avighnesvara, Vinayaka Dan Penglukat. Surabaya: Paramita.

Bawono, Rochtri Agung, and Zuraidah. 2016. "Ragam Seni Hias Majapahit: Penciri Hasil Budaya Majapahit.” Seminar Nasional Seri Bahasa Sastra Dan Budaya, 1-6.

Brandes, J. L. A. 1913. "Oud-Javaansche Oorkonden.” in Verhandelingen van het Bataviaasch Genootschap van Kunsten en Wetenschappen. Batavia: Albrecht \& Co.

Cahyono, M. D. 2012. "Vulkano-Historis Kelud: Dinamika Hubungan Manusia - Gunung Api." Kalpataru Majalah Arkeologi 21(2):85-102. doi: https://doi.org/10.24832/kpt.v21i2.117.

Clarke, David. 1977. "Spatial Information in Archaeology." in Spatial Archaeology. London: London Academic Press.

Getty, Alice. 1971. Ganesa a Monograph on The Elephant-Faced God. New Delhi: Munshiram Manoharlal.

Krishan, Yuvraj. 1982. "The Origins of Ganesa." Atribus Asiae 43(4):285-301. doi: $10.2307 / 3249845$.

Kuswanto. 2009. "Situs Besole: Sisa-Sisa Pintu Gerbang Dari Masa Kadiri." Berkala Arkeologi 29(2):43-54. doi: https://doi.org/10.30883/jba.v29i2.378.

Lutfi, I. 1991. "Telaah Prasasti Palah Dalam Hubungannya Dengan Candi Panataran.” Skripsi. Yogyakarta: Universitas Gadjah Mada.

Machi, Suhadi, and Richardiana Kartakusuma. 1996. Laporan Penelitian Epigrafi Di Wilayah Provinsi Jawa Timur. Jakarta: Pusat Penelitian Arkeologi Nasional.

Moleong, J. L. 2014. Metodologi Penelitian Kualitatif. Bandung: PT Remaja Rosdakarya Offset.

Munandar, Agus Aris. 1995. "Candi Batur Dalam Periode Klasik Muda (Abad 14-15 M)." Laporan Penelitian. Jakarta: Universitas Indonesia.

Rao, Gopinatha. 1968. Elements of Iconography Vol. I. New Delhi: Motilal Banarsidas.

Riana, I. K. 2009. Kakawin Desa Warnnana Uthawi Nagara Krtagama Masa Keemasan Majapahit. Jakarta: PT Kompas Media Nusantara.

Sedyawati, E. 1985. "Pengarcaan Ganeśa Masa Kadiri Dan Sinhasāri: Sebuah Tinjauan Kesenian.” Disertasi. Jakarta: Universitas Indonesia.

Sedyawati, E., H. Santiko, H. Djafar, R. Maulana, W. D. S. Ramelan, and C. Ashari. 2017. Candi Indonesia Seri Jawa. edited by W. D. S. Ramelan. Jakarta: Direktorat Perlindungan Cagar Budaya dan Permuseuman Dirjen Kebudayaan Kemendikbud RI.

Soejono, R. P. 1977. "Sistem-Sistem Penguburan Pada Masa Klasik Akhir Masa Prasejarah Di Bali.” Disertasi. Jakarta: Universitas Indonesia.

Surada, I. Made. 2013. "Ideologi Kedok Muka Kala Pada Bangunan Suci Di Bali Telaah Tentang Ideologi-Religi.” Forum Arkeologi2 26(1).

Teeuw, A., and Tanakung. 1969. Siwaratrikalpa of Mpu Tanakun: An Old Javanese Poem, Its 
Indian Source and Balinese Illustrations. The Hague: M. Nijhoff.

Tim Penulisan Sejarah Nasional Indonesia. 2008. Sejarah Nasional Indonesia II - Zaman Kuno. edited by M. D. Poesponegoro and N. Notosusanto. Jakarta: Balai Pustaka.

Yusuf, Muhamad Satok. 2020. "Blitar Tanah Suci Tiga Kerajaan." Desawarnana - Warta Kepurbakalaan Jawa Timur 20(11):43-51.

Zoetmulder, P. J. 1985. Kalangwan Sastra Jawa Kuno Selayang Pandang. Jakarta: Djambatan.

\section{HASIL DISKUSI}

\section{Tidak Ada Pertanyaan}

